\title{
RACE AND NATION. ON IUS SANGUINIS AND THE ORIGINS OF A RACIST NATIONAL PERSPECTIVE
}

\section{Carlos Amunátegui Perelló*}

\section{ABSTRACT}

Until the beginning of the nineteenth century, the ius soli was the default common standard to acquire citizenship in Europe. Its roots - which were ultimately developed by the Middle Ages' glossators and commentators - were interconnected with the notion of sovereignty and had a working simplicity that avoided the generation of stateless people in various territories of the early modern European states. With the promulgation of the Code Napoléon ${ }^{1}$ this finally came to change with the introduction of the ius sanguinis as the main criterion to recognise nationality. Its imposition was against the whole of the Western legal tradition - one preserved in the Americas because of the independence processes the different colonies experienced from their earlier metropolis - the main scholarship that influenced the code and even the wishes of Napoleón. What made the codifying commission adopt such an unusual standard? We will try to establish that the emergence of the first essays on what came to be known as scientific racism - a dark science, which tends to explain national character in terms of genetic heritage - was at the very base of this development.

Keywords: Ius soli; ius sanguinis; race; nation

1 Code Napoléon / Code civil des Français of 1804 (hereinafter referred to as the French Civil Code).

* Professor in Roman Law, Pontificia Universidad Católica, Chile. 


\section{Introduction}

During 2017, nationality and its acquisition became one of the most debated subjects in the public arena. It was even a mayor concern during the last presidential campaign in the United States, where at least one of the candidates proposed the amendment of the constitutional disposition that provides American citizenship to all people born in its territory - the so called ius soli.

This article intends to draw a simple history of the principles that rule the acquisition of nationality in Western societies, that is to say, the so-called ius soli and ius sanguinis, in order to provide some information about the formation of both principles and the ideas that led to their adoption. This is an historical and comparative exercise, which intends to contribute to the ongoing debate by providing a detailed analysis of the reasons and arguments that underpin the adoption of these two systems to confer nationality.

This article will start with a short history of the acquisition of citizenship up to the French revolution, attempting to establish the foundations of the different Western legal traditions on the topic. Then it will analyse the momentous change in the criteria for nationality attribution that took place during the Napoleonic era the introduction of the ius sanguinis in Western legal tradition - in order to explain its expansion and ultimate predominance in the European legal systems during the nineteenth century.

The third part of this article deals with the ideology behind the introduction of the ius sanguinis and how it may be linked with the emergence of scientific raciscm during the late eighteenth century. Thereafter, some conclusions will be drawn.

\section{The origins of the ius soli and the ius sanguinis}

Ius soli and ius sanguinis are the usual terms employed to refer to two different systems of acquisition of nationality on which most of the Western societies tend to base their institutions. However, despite the Latin terminology there are no such Roman institutions to be found. In fact, the rules of acquiring citizenship in the Roman world were quite different from our own. Under Roman law, citizenship could be acquired by birth, by liberation, or through a special grant of the city. We are only concerned with birth, where the rule is that a son born from marriage acquired the citizenship of his father, ${ }^{2}$ while if he was born from an extra-marital relationship, he would follow the citizenship of his mother. ${ }^{3}$ The underlying reasons for such attribution were imbedded in the Roman perceptions of family ties. The link

2 D 1519 Celsus libro 29 digestorum. Cum legitimae nuptiae factae sint, patrem liberi sequuntur: volgo quaesitus matrem sequitur.

3 D 1524 Ulpianus libro 27 ad Sabinum. Lex naturae haec est, ut qui nascitur sine legitimo matrimonio matrem sequatur, nisi lex specialis aliud inducit. 
between the members of a group was based on the fact that they had all been under the patria potestas of the same pater, usually the eldest man in the group, who had absolute power over its members, including the possibility of killing them. ${ }^{4}$ These members were the agnati, and were also known as familia proprio iure, for only this relationship created legal consequences. ${ }^{5}$ The kinship relationships outside this narrow legal framework were usually without legal consequences and were regarded as natural - common to all men and animals alike ${ }^{6}$ as opposed to legal.

This strict criterion to confer citizenship in Roman law underwent a substantial change at the beginning of the third century. In 212 AD emperor Antoninus Caracalla conferred Roman citizenship on all the inhabitants of the Roman Empire. ${ }^{7}$ Although the reasons for and consequences of this grant remain controversial, for present purposes the key feature of this important act was a big change regarding the criterion for assigning citizenship during late antiquity: one from power-based family relations to residence. Residence in the Empire thus became the determinant factor for granting citizenship, while the later Roman Empire was slowly becoming a territorial state. Roman citizenship meant that there was only one legal system in

4 The peculiar nature of family relationships in Roman law has been under furious debate for over a century. As a matter of fact, there seem to be two main explanations for its peculiar character. On the one side, family relationships have been envisioned as holding a political nature. Each family would be a political unit that would be ruled by a sovereign, commanding individual, the pater familias (see Bonfante 1963: 7ff). Another explanation would point to the economic unity of the family. In Republican Rome there was no single word to describe property, so the power relations that would constitute the core of the family would mimic the power a man had over material goods to use and dispose of them (see Arangio-Ruiz 1914: 109-158; Voci 1953: 101; Kaser 1960: 47; Pugliese 1985: 11).

5 D 5061952 Ulpianus libro 46 ad edictum. Familiae appellatio refertur et ad corporis cuiusdam significationem, quod aut iure proprio ipsorum aut communi universae cognationis continetur. Iure proprio familiam dicimus plures personas, quae sunt sub unius potestate aut natura aut iure subiectae, ut puta patrem familias, matrem familias, filium familias, filiam familias quique deinceps vicem eorum sequuntur, ut puta nepotes et neptes et deinceps. Pater autem familias appellatur, qui in domo dominium habet, recteque hoc nomine appellatur, quamvis filium non habeat: non enim solam personam eius, sed et ius demonstramus: denique et pupillum patrem familias appellamus. Et cum pater familias moritur, quotquot capita ei subiecta fuerint, singulas familias incipiunt habere: singuli enim patrum familiarum nomen subeunt. Idemque eveniet et in eo qui emancipatus est: nam et hic sui iuris effectus propriam familiam habet. Communi iure familiam dicimus omnium adgnatorum: nam etsi patre familias mortuo singuli singulas familias habent, tamen omnes, qui sub unius potestate fuerunt, recte eiusdem familiae appellabuntur, qui ex eadem domo et gente proditi sunt.

6 D 11113 Ulpianus libro primo institutionum. Ius naturale est, quod natura omnia animalia docuit: nam ius istud non humani generis proprium, sed omnium animalium, quae in terra, quae in mari nascuntur, avium quoque commune est. Hinc descendit maris atque feminae coniunctio, quam nos matrimonium appellamus, hinc liberorum procreatio, hinc educatio: videmus etenim cetera quoque animalia, feras etiam istius iuris peritia censeri.

7 D 1517 Ulpianus libro 22 ad edictum. In orbe Romano qui sunt ex constitutione imperatoris Antonini cives Romani effecti sunt. 
the Empire - in contrast with the different personal laws of the previous era - since there was only one ruler and (after the adoption of Christianity) one God.

However, the legal framework of citizenship came into conflict with the economic realities of the later Empire. During the Late Republic and the Early Empire Rome had become a market society. ${ }^{8}$ In this context, geographical mobility was one of the main features that Rome's dominion over the Mediterranean world brought to antiquity. Cicero, defining the spirit of ancient cosmopolitan states that patria est ubicumque est bene, ${ }^{9}$ that is, that one's homeland is wherever one feels good. The myth of Romulus founding Rome as an asylum that welcomed anyone who wanted to migrate "might have been designed expressly to legitimise a citizen body based not on birth but on the desire to become Roman". ${ }^{10}$

Although the needs of the productive economy were satisfied partially with a free labour market, ${ }^{11}$ the pressure for mobilising labour triggered a massive heterogeneous migration based on slavery, involving millions of captives from the wars conducted by Rome being sold at markets.

During the Late Empire, Rome's market economy was shrinking. The catastrophic consequences of the third-century crises, and the extended de-monetisation of the Empire $^{12}$ led to a contrary movement in order to fixate manpower. A slave workforce became rare, and was replaced by coloni in large areas of the Empire. ${ }^{13}$ These coloni were poor citizens, nominally free, but bound to the land they were working by ties that in the Middle Ages would give rise to feudalism.

A contradiction was the result, for while the economic pressures were demanding the control of movement within the Empire, the legal framework granted Roman

8 The presence or absence of markets in the Roman economy is a fiercely debated subject. Nowadays discussion commences with the work of Finley (1999), who proposed a weak role for markets for the classical world, mostly for the big metropolises of antiquity, like Rome or Alexandria, while the rest of the Empire would remain under an economic model based on limited commerce in the context of a peasant economy. Several academics have followed his model, proposing low levels of monetisation and restricted local markets (see Finley 1999: 95-122; Crawford 1970: 4048; Meikle 2002: 233-250). This is known as "primitivism". Since the beginning of the twentyfirst century, an alternative perspective has taken root, proposing deeper levels of monetisation throughout the Empire and a proper market economy for the Late Republic and Early Roman Empire, which accordingly has been called "modernism" (see Greene 1990: 45-66; von Reden 2012: 266-285). For the complete debate, see Bang 1997: 1-21.

9 Tusc Disp 5108.

10 See Neville 2006: 15167.

11 Free labour in late Republican and Imperial Rome has been a topic of intense recent debate, with some scholars suggesting that beside the slave market, there was also a market for free labour in the late Republic (see Harris 2011: 1546-578; Kehoe 2012: 114-131). The most extreme approach, suggesting the prevalence of a market of free labour for Rome, is Temin 2013: 114-138.

12 See Lo Cascio 2000: 307-326.

13 For the economic implications of colonate, see Marcone 1997: 151-174. See, further, on colonate's legal framework, Sirks 1999: 419-430; Sirks 2008: 120-143; Santilli 1999: 275-292. 
citizenship to all free people of the Empire. New legal devices were designed in order to restrict their mobility and migration. A whole new set of regulations was produced to settle the productive forces of the Empire. A labour law of sorts was created, which aimed to limit workers' mobility and assign them to their place of origin. During the time of Constantine the Great, field workers could not leave their jobs until the harvest was finished, ${ }^{14}$ while a little later, Valentinian and Valens prohibited them from leaving their lands of origin at all. ${ }^{15}$ Imperial governors were charged with the task of returning them to their lands of origins if they were apprehended elsewhere, ${ }^{16}$ thus establishing a formal prohibition to either include them in any city census or grant them a right of residence. ${ }^{17}$

In this context, the question of a person's origin became quite relevant once again. In the Later Empire it was a person's origin which conferred the right to establish residence, and residence consequently acquired a status equivalent to citizenship. ${ }^{18} \mathrm{~A}$ person's origin was determined at his birth, according to his father's origin. A series of imperial decisions made this point clear. ${ }^{19}$ In the new Christian empire, born from the ashes of the third century, Roman citizenship was universal although there was a kind of denizenship that depended on birth and which ultimately gave the right to establish residence in a particular region of the Empire.

After the disintegration of the western part of the Empire, common legal rules disappeared during the Dark Ages and only re-emerged once the invasions and depopulation receded to give way to a new world which eventually adopted earlier legal rules.

14 C 11481.

15 C 11483.

16 C 11486.

17 C 114811.

18 Centuries later the medieval commentator Baldus said that residence was a kind of (quasi) citizenship: Baldo Ubaldi in I-XI Codicis Libros Commentaria, 1577, 7: Nam ratione domicilii est effectus sub illa lege: quam quasi civis est.

19 This was decided in a series of decisions which started with the emperor Antoninus Caracalla and continued down to Constantine:

C 10391 Imperator Antoninus. Cum te Byblium origine, incolam autem apud Berytios esse proponis, merito apud utrasque civitates muneribus fungi compelleris. ${ }^{*}$ ANT. A. SILVANO. ${ }^{*}<A$ $X X X>$.

C 10393 Imperator Philippus. Filios apud originem patris, non in materna civitate, etsi ibi nati sunt, si modo non domiciliis retineantur, ad honores seu munera posse compelli explorati iuris est. * PHILIPP. A. PATROCLO. * $<A X X X>$.

C 10394 Imperatores Diocletianus, Maximianus. Origine propria neminem posse voluntate sua eximi manifestum est. * DIOCL. ET MAXIM. AA. SECUNDO. ${ }^{*}<A X X X>$.

C 10395 Imperator Constantinus. Si quis vel ex maiore vel ex minore civitate originem ducit, si eandem evitare studens ad alienam se civitatem incolatus occasione contulerit et super hoc vel preces dare temptaverit vel qualibet fraude niti, ut originem propriae civitatis eludat, duarum civitatum decurionatus onera sustineat, in una voluntatis, in una originis gratia. ${ }^{*}$ CONSTANT. A. AD MAXIMUM VIC. ORIENTIS. *<A 325 PP. VIII K. IAN. PAULINO ET IULIANO CONSS.>. A main problem seemed to be the status of students, who wandered around different cities of the Empire. 
When, eventually, Roman legal rules re-appeared at the beginning of the twelfth century, the Glossators quickly extracted legal rules from the ancient texts. The different passages treating citizenship and residence in the Corpus Iuris were identified and commented on in an attempt to give a synchronic sense to what was essentially a group of diachronically diverse rules. On the one hand, there was the concession of Roman citizenship to all inhabitants of the Empire, while - on the other hand - there was a set of rules that distinguished between people's origin (origo). In this context, the glossator Azo commented that a person could be a member of a city (municipes, from munus, burden, to share the burdens) by birth, liberation or by option. This membership was his real citizenship. ${ }^{20}$

Although the old Roman Empire had dissolved into different kingdoms hundreds of years before, during the Middle Ages there was still a sense of unity which involved political, legal and religious dimensions. There was one law - the recently re-discovered Roman law that was called the ius commune; one Emperor - the German Emperor, who was also King of Italy and crowned by the Pope; and one Church.

During the later Middle Ages, a new conception of the relationship between sovereign and territory emerged, one where each king would hold the sole legal authority in his kingdom, well beyond the grasp of the German emperors, who would be stripped of their universal aspirations and considered kings only of the lands they could control.

In this context, Baldus from Ubaldi, a fourteenth-century commentator, explicitly stated that the Emperor could not rule over those who were not his direct subjects ${ }^{21}$ and could not impose rules on those which were not under his allegiance. ${ }^{22}$ As far as allegiance was concerned, it was addressed in a new fashion, albeit on the basis of interpreting the old texts. Baldus established a difference between the citizens by origin and those who could acquire citizenship by other means. ${ }^{23}$ Those who were citizens by origin were considered natural citizens (cives naturales). He stated that citizens by origin were those who were born in a city. ${ }^{24}$ Therefore, if someone was born in Florence, he was Florentine by origin.

20 Azonis, Ad singulas leges XII librorum Codicis Iustinianei, 1596, 1097: Municipes aut nativitas facit, aut manumissio aut optio. Et dicuntur propie municipes, quasi muneris participes in civitatis sic recepti, ut munera nobiscum facerent ... tunc municipes dicamus cuiuscunque civitatis, ut puta cives Campanos, Puteolanos ...

21 Baldo Ubaldi, Ad singulas leges XII librorum Codicis Iustinianei, 1577, 5: Imperator non imponit leges nisi subditis.

22 Idem at 6: Imperator nec de iure, nec de facto possit imponere legem non subditis.

23 Baldo Ubaldi In primam digesti veteris paterm commentaria, 1577, 33.

24 Baldo Ubaldi Ad singulas leges XII librorum Codicis Iustinianei, 1577, 278: In loco originis, et in colatus, cogitur quis subire onera ... Nota ex eo, quod dicit, Biblium ex origine, quod item est, quod dicere Florentinum, et natum de Florentia, quod declara, ut plene dixi in l.j. ad munic ... De incolis, et ubi quis domicilium habere videtur. Et de his, qui studiorum causa in alia civitate degunt. 
In this regard the new states that emerged in Western Europe systematically adopted this rule, which would some centuries later came to be called ius soli. Following Baldus's doctrine, any man born in the territory of a kingdom became its citizen.

Already in the thirteenth century, the kingdom of Castillia established that the law of the land was mandatory even for foreigners. ${ }^{25}$ Even more, it expressly stated that a man was a natural citizen of the place where he was born. ${ }^{26}$ When Spain came to be a state after the marriage of Elizabeth and Ferdinand, these rules remained in force, and the ius soli became the law of the land and remained so until the beginning of the nineteenth century. ${ }^{27}$

In France the situation was similar. In 1315, by a royal decree of Louis X, it was established that by natural law whoever was born in France, was to be a Frenchman, ${ }^{28}$ thus following the doctrine of Baldus. In 1515, this was confirmed by a decision of the Parliament of Paris. ${ }^{29}$ During the eighteenth century the doctrine was wellestablished and Pothier $^{30}$ summarised it as follows:

The citizens, the true and natural French, following Bacquet's definition, are those born within the limits of the French dominions.

England, with the well-known case of Calvin $v$ Smith in $1608,{ }^{31}$ adopted the very same rule, establishing that whoever was born in the territories under the dominion of the Engish king was English. Whether the rule was a reception of the ius commune or a parallel development of English law, remains to be settled. Anyhow, Blackstone ${ }^{32}$ summarised the position as follows:

25 Gregorio López, Las Siete Partidas Glosadas, 1555, 8: “Todos aquellos que son del señorío del fazedor de las leyes, sobre las cosas que pone, son tenudos de las odedecer e guardar, e juzgarse por ellas ... E esso mismo dezimos de los otros.

26 Idem 68: "Por mayor tovieron los sabios antiguos aquella naturaleza que los omes han con la tierra por nascer en ella."

27 The Novísima Recopilación of 1805 stated a new rule. To become a churchman one had to be born in the lands that belonged to the Spanish territories from Spanish parents $(17, t$ 14, 11 from the Novísima Recopilación). Nevertheless, during the early nineteenth century this rule was interpreted as meaning that only men that were born in the Spanish territories from Spanish parents were Spanish naturals. See Bello 1886: 107; Asso del Río \& M de Manuel y Rodríguez 1806: 35; Tapia García 1828: 7; and Escriche 1875: 255.

28 See Dalloz \& Dalloz 1840: 199.

29 Berdah 2006: 142.

30 1846: 17: Les citoyens, les vrais et naturels Français, suivant la définition de Bacquet, sont ceux qui sont nés dans l'etendue de la domination française.

31 Calvin v Smith 77 Eng Rep 377 (KB 1608). A man named Robert Calvin was born in Scotland after its subjugation to the English Crown. When he died he left lands in England. If he was considered English, he could leave them to his heirs, but because he was not born in England, this issue came to trial. Eventually it was decided that whoever was born in the territories of the Crown, was under the allegiance of the King, and therefore English (see Price 2013: 73-145; Dumbraya 2014: 1537).

32 1826: 366. 
The first and most obvious division of the people is into aliens and natural-born subjects. Natural-born subjects are such as are born within the dominions of the crown of England, that is within the ligeance, or as it is generally called, the allegiance of the king; and aliens, such as are born out of it.

By the eighteenth century the common rule in Western European states was that citizenship was attributed at birth according to the place where the person was born. Baldus's interpretation of the old Roman rules and the political requirements of the emerging states were the two forces that informed this phenomenon. Still, there were cases when the parents' nationality was taken into account in order to grant nationality to their descendants when they were not born in the territory of the Crown. An example would be the French Parliament - a kind of appeal court - which regularly conferred citizenship on this ground from the sixteenth century onwards. This was, however, rather exceptional. ${ }^{33}$

Contrary to the belief of modern scholarship,$^{34}$ citizenship was considered one of the three statuses a person could hold during the Ancien Regime - the two others being freedom and family status. ${ }^{35}$ Citizenship could not be changed ${ }^{36}$ and it was one of the fundamental sources of rights and duties a person acquired at birth.

The system worked well. The largest and most important states of modern Europe adopted it, and statelessness was next to impossible. Although the frontiers of modern Europe changed from time to time, citizenship did not seem to be a pressing matter, for the rules were so clear that the determination of citizenship through the place of birth was even believed to be a rule of natural law. All of this would change during the French Revolution.

\section{Revolution and change}

The French Revolution was the most important historical event during the last two hundred years, and many important features were restructured during those

33 See Weil 2008: 1 147; Berdah 2006: 142.

34 For instance, Weil 2008: I 100 states that "(f)rom this point on [the enactment of the French Civil Code] nationality became a right attached to the person: like the family name, it was transmitted by fatherhood; it was attributed at birth; it was no longer lost if its holder established residency abroad".

35 In most basic law books, which after the sixteenth century usually followed the model of the Justinian Institutes, the matter was treated in relation to the different status a person might hold normally in the first book, right after freedom and before family status. This came directly from Roman influence. Gaius' Institutes - and therefore Justinian's - treats citizenship at the very end of his discussions about the status of liberated slaves. See, eg, the very influential seventeenthcentury text of Arnoldus Vinnius (1755) at 44: Institutionum Imperialium Commentarius which was the basic text for first-year students all around Europe and even in the Spanish American colonies.

36 C 10394 Imperatores Diocletianus, Maximianus: Origine propria neminem posse voluntate sua eximi manifestum est. ${ }^{*}$ DIOCL. ET MAXIM. AA. SECUNDO. ${ }^{*}<A X X X>$. 
few stormy years. At first glance, the ius soli was not opposed to the revolutionary ideals. As a matter of fact, its universal tone and overview was appealing for legal intellectuals, although other principles were implemented in order to broaden its scope. During the Revolution, together with being born in France or born to a French father, residence - the mere fact of living in France - became sufficient to claim French citizenship. ${ }^{37}$ In addition, according to the ideals of the Revolution some of the most outstanding intellectual heroes of the time - people who had never lived in France or had no apparent connection with the country - were granted French citizenship on condition that they would live in France, as was the case with Thomas Payne, George Washington and Jeremy Bentham, among others. ${ }^{38}$ Among the different criteria for obtaining French citizenship, the most important - at least for the public eye - remained the place of birth. In the texts that aimed to educate the French people politically, the definition of a French citizen was quite simple: anybody who was born in France. ${ }^{39}$

Although later constitutions of the French Revolution somehow restricted the right to French citizenship, the ius soli was still its main feature until the enactment of the French Civil Code in $1804 .{ }^{40}$ Still, already during the discussions of the Constitution of 1799 - the one written immediately after the coupe d'état that empowered Napoleon - a new tendency emerged restricting French citizenship to those who were born to French parents, thus leaving stateless a growing section of the population. ${ }^{41}$ This would later be known as the ius sanguinis. Although this line of thought was blocked on the eve of Napoleon's rule, it later - during the composition of the French Civil Code - returned, and eventually imposed itself against the French legal tradition, the generous original aims of the Revolution, and even the wishes of Napoleon himself.

37 In fact, the Constitution of 1791 even gave citizenship to those who were descendants of people expelled from France for religious reasons. Article 2, which covers the problem, states as follws: Article 2. - Sont citoyens français:

- Ceux qui sont nés en France d'un père français;

- Ceux qui, nés en France d'un père étranger, ont fixé leur résidence dans le Royaume;

- Ceux qui, nés en pays étranger d'un père français, sont venus s'établir en France et ont prêté le serment civique;

- Enfin ceux qui, nés en pays étranger, et descendant, à quelque degré que ce soit, d'un Français ou d'une Française expatriés pour cause de religion, viennent demeurer en France et prêtent le serment civique. See Brubaker 1993: 6; Weil 2008: 1.189.

38 Berdah 2006: 143; Weil 2008: 1.200.

39 D. Quels sont ceux qu'on appellé en France citoyens $R$. Tout homme né et domicilié en France àgé de 21 ans accomplis, tout étranger àgé de 21 ans accomplis qui domicilié en France depuis d'une année. Anonimus (1793-1794=2nd year of the Republic): 5.

40 See the Constitutions of 1793, art 2; 1795, art 8; and 1799, art 2.

41 Later known as the ius sanguinis: the term comes from the middle of the nineteenth century, from the work of the Exegetic School. 
The coupe that took the young general to power (9 Nov 1799) was backed by many of the leading figures of the Revolution, among whom Emmanuel-Joseph Sieyès was one of the most conspicuous. A new Constitution was to be enacted in order to give legitimacy to Napoleon's rule. Nevertheless, conflicts emerged between Napoleon and Sieyès regarding this legal document. Sieyès wanted a fairly balanced Constitution that would not grant absolute power to any man or institution, but Napoleon had a different opinion. Finally, Sieyès lost the struggle and had to abandon his propositions, leaving the way open for the new Napoleonic Constitution. Among Sieyès propositions was granting French citizenship - at this time the term "nationality" was not in use ${ }^{42}$ - to those who were born either in France or abroad to a French father. ${ }^{43}$ This proposition was opposed by Napoleon himself, with the backing of Pierre Daunou ${ }^{44}$ who supported the traditional notion of the ius soli. Finally, article 2 of the Constitution of 1799 stated as follows: ${ }^{45}$

Any man who was born and has residence in France, who, having become twenty-one years old, inscribes in the civic register of his communal register, and who has since stayed a whole year in the territory of the Republic, is a French citizen.

The article does not define nationality, but citizenship. At the time citizenship was understood as the right actively to participate in public affairs, supposing that the citizen had also the status of national. The article was understood as granting French nationality to those born in France, while it gave citizenship to those who met the other requirements, namely being a male of at least twenty-one years of age who had performed the required inscription and lived in France for a year. ${ }^{46}$

Shortly thereafter, during the discussion of the French Civil Code, the problem re-emerged. A commission to draft the Code was appointed in 1800, comprising François Denis Tronchet, president of the Court de Cassation, Jean-Étienne-Marie Portalis and Félix Julien Jean Bigot de Préameneu. The work of this commission was discussed with the Conseil d'État, where Napoleon himself participated in the discussion, together with Théophil Berlier, Antoine Jacques Claude Joseph (Compte de) Boulay de la Meurthe, and Jean Jacques Regis de Cambacérès who had already drafted several Civil Codes and was the second consul with Napoleon.

During the session of 14 Thermidor of the ninth year of the Revolution (1 August, $1801)^{47}$ the Conseil d'État discussed the relevant article (7) regarding nationality. ${ }^{48}$

42 See Weil 2008: 1100.

43 Idem 1299.

44 Idem 1304.

45 Article 2-Tout homme né et résidant en France qui, âgé de vingt et un ans accomplis, s'est fait inscrire sur le registre civique de son arrondissement communal, et qui a demeuré depuis pendant un an sur le territoire de la République, est citoyen français.

46 Ngaire Heuer 2007: 129; Weil 2008: 1282.

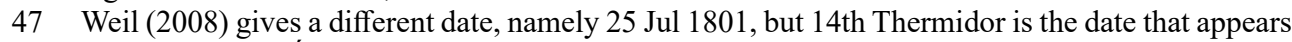
in the Conseil d'État's archives. See Weil 2008: 1304.

See Conseil d'État 1841: 12. 
Tronchet proposed that only the son of a Frenchman was to be French, whether he was born in France or in a foreign country. This proposition was immediately rejected by the Council. Cambacérès pointed out that an abandoned child would not bear any nationality. Boulay stated that the Constitution already granted the right of being French to those who were born in France, even from foreign parents. Napoleon proposed to replace the article simply by the following: ${ }^{49}$ "Any individual born in France is French." Tronchet defended his view by arguing that imposing French nationality on anyone whose parents were not French just because he was born in French territory, would be unfair and against the established principles of civil law. Napoleon pointed out that a child born in France would have a French upbringing and that as such would make him French. Tronchet's position was swiftly rejected and the Conceil d'État adopted Napoleon's view. The Conceil d'État's original proposition contained both the ius soli and the ius sanguinis to grant French nationality at birth.

The draft Civil Code had to be approved by the Tribunat, an assembly that, among other duties, was tasked to oversee the legislative process. It was presided over by Pierre Daunau, the same man that had already aided Napoleon to gain approval of the 1799 Constitution. Accordingly, everything was supposed to go smoothly. However, it did not. There was strong opposition by the Tribunat to many of the propositions contained in the draft. The opposition to the ius soli was headed by Joseph-Jerome (Compte de) Siméon, who compiled a report on the matter. ${ }^{50}$ Siméon argued that while the son of an Englishman born in France would be considered French, the son of a Frenchman born in England would not necessarily be considered English. He argued that this so-called Frenchman could still take his wealth back to England at any time. ${ }^{51}$ According to Siméon feudalism was linked with the ius soli, and that would merely be a side effect of feudalism..$^{52}$ Ultimately the rule was rejected and the commission had to revert to Tronchet's proposition. The text was again presented to the Tribunat and approved on 18 March 1803 with ius sanguinis as the only criterion to confer French nationality at birth. ${ }^{53}$

49 "Tout individu né en France, est Français" in Conseil d'État 1841: 12.

50 The chapters of the French Civil Code were presented to the Tribunat on 11th Frimaire and a commission was formed to analyse the matter on the next day, manned by Boisjolin, Boissy, Caillemer, Chabot, Siméon, Thiessé and Roujoux. A report from the commission was presented on the 25th of the same month by Siméon, while the discussion continued on 5th Nivôse, with arguments from Malherbe supporting the ius soli.

51 See Coin-Delisle 1865: 225.

52 Weil 2008: 1395 . The complete report is available in Mavidal \& Laurent 1864: $165 \mathrm{ff}$. According to Simeon feudalism was linked with the ius soli. He does not explain in which way, but he states so expressely. His reasoning probably pointed to the fact that during the Anciént Régime the ius soli was the prevalent form to acquire French citizenship and because he believed that the idea of a French racial nation was more modern.

53 Weil 2008: 1415. 
It is not easy to recount developments between 1799 and 1803, when the principle of ius sanguinis emerged and became the dominant feature of the new French legal system. Up to then, this principle was universally adopted by all European powers and had the general approval of leading political thinkers of the time. ${ }^{54}$ Most of them did not give the matter much thought, while legal scholars usually accepted Baldus' interpretation of Roman texts as the standard rule on the matter. ${ }^{55}$ It has been pointed out that it was Tronchet's background as a lawyer (who had pleaded in favour of the ius sanguinis during the old regime for his clients) and his respect for Roman law that would explain his approach favouring the exclusivity of the ius sanguinis. ${ }^{56}$ However, his preference for the ius sanguinis should not have excluded the ius soli, especially against a tradition that was deeply ingrained in the predominant conception of the modern state.

There are probably other motives that might have inspired the final decision about the exclusion of the ius soli from the French Civil Code. While Napoleon's cannons were conquering Europe, a new and dark science quietly emerged in the European panorama. It whispered black words to its intellectuals and gave a whole new perspective to an old prejudice, namely scientific racism.

\section{Scientific racism}

Racism is not new to the Western mind. Many kinds of prejudices have been built into the long history of Europe, and they were eventually transmitted worldwide with the expansion of European civilisation during the sixteenth and seventeenth centuries. Some of the most illustrious thinkers of the Enlightenment displayed a rather crude racial perspective.

One of the first and more influential ideas about race in France was systematically put forward by Henri (Compte) de Boulainvilliers in his Histoire de l'Ancien gouverment de la France (1727). His central thesis was that the French nation consisted of two different races, namely a Germanic race that descended from the Francs which formed the core of the nobility, and a Gallo-Roman race that was subdued by the Germanic race and that was predominant among the commoners or third estate. For him, the French nation was a sort of union, founded by the king, between the Francs (in his language simply the French) and the Gauls. ${ }^{57}$ The

54 The only exception we have been able to find was Pufendorf, who believed in a contractual theory of the State, where the descendants of the first citizens - those who had accepted the social contract to form the city - would be properly called citizens. See Pufendorf 1682: 126 =2 613 .

55 We should say, anyhow, that some legal scholars pointed out that Baldus' interpretation was flawed and that Roman citizenship was transmitted at birth regarding the father's citizenship. See, eg, Cujacius (1663), o. 33 Recte Romanum interpretamur Roma oriundum qua appellatone, et in jure nostro semper notatur origo paterna, non origo propia et natale solum.

56 Weil 2008: 1350.

57 See de Boulainvilliers 1727: 32-36. 
dominant position of the aristocracy was founded on the conquest of Gaul by the Francs. Miscegenation, which commenced with the coronation of Huge Capeto, endangered the stability of the nation. His views became common in the eighteenth century and even made their way into Diderot's Encyclopédie. ${ }^{58}$

During the eighteenth century, many new scientific disciplines took root in Europe. Before, most of the organised knowledge, whether about nature or mankind, was considered to be part of philosophy. However, after the inexplicable successes of Modern Europe in physics and cartography, new sciences emerged, with their own methods and objects of study. Many branches of philosophy were cut off and a whole range of new sciences emerged. This is the era of Lavoisier, the father of modern chemistry; of Adam Smith, the father of modern economy; and also of Carl Linnaeus, the father of scientific taxonomy.

Carl Linnaeus was a well-recognised scholar who made a major contribution to biology by classifying all known natural species according to gender. His major work, Systema naturae per tria regna naturae, published in 1735, was divided into three parts, which corresponded to the three natural kingdoms, namely one for minerals, one for vegetables, and one for animals. For the animal kingdom, he devised a classification of all the different types of animals known to man, including a gender for the mammals (mammalia), divided into different branches, one of which was occupied by the primates among which one could find man (homo) ${ }^{59}$ Humans were classified into six different types: Ferus (wild), Americanus (American), Europaeus (European), Asiaticus (Asian), Afer (African) and Monstruosus (monstrosities). ${ }^{60} \mathrm{To}$ each human type, a set of characteristics such as skin colour, other physical features and moral peculiarities, was attached. We do not have to go into the particularities of this distinction, but we might, for instance, say that an Afer was black, phlegmatic, clumsy and ruled by caprice, while the Americanus was described as being choleric, dark-skinned, easy to laugh and ruled by custom, while the Europeaus was white, very smart, and ruled by ceremonies.

Although the features contained in these human types were not new, it is important to point out that this was the first time that a description of human races was embedded in a scientific work - one that places man in its natural context as one of many other species according to objective standards such as geography and skin colour. Racism suddenly became part of a new science that was being developed by one of the brightest minds of European Enlightenment. The consequences would over time become devastating.

58 In fact, in the voice Française you can find a quick overview of Boulainvilliers' theory distinguishing between the two races that constitute the French nation.

59 Linneaus 1757: 18.

60 Idem 20-22. According to Bethencourt, in the first edition of 1735 ferus and monstrosus were not included, and neither the descriptions that followed in the edition we worked with. See Berthencourt 2013: 16121. 
This new science was taken up by one of the most influential thinkers of the French Enlightenment, Georges-Louis Leclerc, compte de Buffon (1707-1788). As one of the youngest members ever of the French Academy and Director of the Jardin des Plantes, Buffon had an impeccable scientific reputation. He wrote an astonishing natural history in thirty-six volumes, which elevated him to one of the most prominent scientific figures of his generation. His work influenced the Encyclopaedia of Diderot and had a huge effect on the European Enlightenment. One of his most controversial works concerned men and human races, the Histoire naturelle de l'homme et de la femme. There, following Linnaeus's lead, he classified men according to races, featured by skin colour, general body shape and moral character ${ }^{61}$ His work constitutes a vast description of different human types on different continents, sometimes describing them almost country by country. Racial features were, according to Buffon, the consequences of climate, food and costumes. ${ }^{62}$ Miscegenation was one of the main features that might affect a race, either improving or weakening it,$^{63}$ and creating new nations, as in the case of the Tartars who were a mixture of Chinese and Russians.

Racial degeneration and interbreeding was a much-debated topic in the intellectual circles of the Enlightenment. Even Kant, under the influence of Buffon, ${ }^{64}$ wrote a series of articles on race, where he points that the main difference between races was that when they mixed, they produced half-breeds, while when members of the same race interbred, they conferred on their off-spring randomly the features of each parent. ${ }^{65} \mathrm{He}$ explicitly opposed racial mixing and feared it. ${ }^{66}$

Montesquieu was also influenced by this science. He opined that different climates affected the physical and moral constitutions of the inhabitants of a region, ${ }^{67}$ causing people from cold climates to be bolder and stronger than those from warm climates. According to his analysis, people from India would be "naturally a pusillanimous people", ${ }^{68}$ and that these matters should be taken into account for successful legislation. ${ }^{69}$

Although there existed an intellectual climate that favoured the inclusion of racial ideas in legislation, we should nevertheless evaluate some of the ideas of the proposers of the ius sanguinis as the sole means of becoming part of a nation in order

61 Leclerc (Compte) de Buffon 1834: 173.

62 For a general description see Berthencourt 2013: $16153 \mathrm{ff}$.

63 Leclerc (Compte) de Buffon 1834: 175.

64 Mikkelsen 2013: 1266.

65 See, eg, his 1788-essay "On the Use of Teleological Principles in Philosophy" where he defines races as common lines of descent, and then expressly treats the matter of miscegenetion. For a recent translation see idem $14306 \mathrm{ff}$.

66 Idem 1328.

67 Montesquieu 1772: 283-286.

68 Ibid 283-286.

69 Idem 379. 
to establish if there had been a racist motive. This is, admittedly, slippery ground, for often the motives are not clearly stated, but indirectly proposed or related to other matters which would somehow affect the legislative position. For instance, Tronchet, the main defender of the ius sanguinis in the Conceil d'État, cannot be directly linked to any of these racial theories. He was a rather conservative man, who defended Louis XVI as a lawyer and before the Revolution pleaded many cases in favour of the application of the ius sanguinis for his clients. Although he had a keen interest in science, this does not necessarily mean that he supported the racial theories of his time.

The matter is somehow different when analysing the works of Sieyès. In his famous essay, Qu'est-ce que le Tiers état, he relies on Boulainvilliers' thesis to deny the validity of the right of conquest as a mean of justifying the nobility's claim over the commoners or Third Estate. ${ }^{70} \mathrm{He}$ explicitly rejected the view that the Franks' conquest of Gaul would confer on the aristocracy a right to dominate the Gallo-Roman population. Therefore, according to him, the Third Estate, namely the commoners in the nomenclature of the Ancient Regime, could reclaim their rights and demand a new Constitution.

Although Sieyès ${ }^{71}$ holds and defends a legalistic idea of the nation, where having a common law and a common legislative power would be its defining features, he also seems to have a somehow naturalistic idea of the nation, where the nation would pre-exist any positive rule and would emerge directly from the natural order. ${ }^{72}$ In fact, in having a different legal order and legislative representation, the aristocracy, namely the Franks, would exclude themselves from the nation. ${ }^{73}$ In this sense, the Third Estate would really be the only nation in France, and the descendants of the Franks - the nobles - should not be regarded as French citizens. ${ }^{74}$

70 Sieyès 2002: 8: "Que si les aristocrates entreprennent, au prix même de cette liberté, dont ils se montreraient indignes, de retenir le peuple dans l'oppression, il osera demander à quel titre. Si l'on répond à titre de conquête, il faut en convenir, ce sera vouloir remonter un peu haut. Mais le tiers ne doit pas craindre de remonter dans les temps passés ..."

71 "Qu'est-ce qu'une nation? Un corps d'associés vivant sous une loi commune et représentés par la même législature" (idem 5).

72 "la nation se forme par le seul droit natural. Le gouvernement, au contraire, ne peut appartenir qu'au droit positif" (idem 54).

73 "Ainsi, ses droits civils en font déjà un peuple à part dans la grande nation. C'est véritablement imperium in imperio" (idem n 68 5). "Il faut entendre par le tiers état l'ensemble des citoyens qui appartiennent à l'ordre commun. Tout ce qui est privilégié par la loi, de quelque manière qu'il le soit, sort de l'ordre commun, fait exception à la loi commune, et par conséquent, n'appartient point au tiers état" (idem 6).

74 Idem 8: "La nation, alors épurée, pourra se consoler, je pensé, d'être réduite à ne se plus croire composée que des descendants des gaulois et des romains. En vérité, si l'on tient à vouloir distinguer naissance et naissance, ne pourrait-on pas révéler à nos pauvres concitoyens que celle qu'on tire des gaulois et des romains vaut au moins autant que celle qui viendrait des sicambres, des welches et autres sauvages sortis des bois et des étangs de l'ancienne Germanie?" 
Although Sieyés is arguing for equality, there is a racial element in his argument, which derives directly from one of the earliest theories of scientific racism in France. This might explain his preference for ius sanguinis in the discussions for the 1799 Constitution.

In the case of Siméon, the main antagonist of ius soli in the Tribunat, the link is somehow stronger. In his speech in the Tribunat there are only faint links to race, such as when he argues that the son of a Frenchman who has renounced his nationality should be immediately admitted to citizenship because "he has French blood in his veins". ${ }^{75}$ It seems clear that he is afraid of the effects that foreign people would have on the French population, for he stated that "we seriously expose ourselves to receive those without a homeland who want to enrich themselves with our rights, while infecting us with their vices". ${ }^{76}$ Some nineteen years later, the same man vehemently criticises the liberation of slaves, saying that the tree of liberty could produce poisonous fruit if its not properly cultivated. ${ }^{77}$ Granting slaves immediate freedom was an excess, a simple fanatisme de la liberté. ${ }^{78}$

During the second session where the matter was discussed, on 5th Nivôse, the tribune JA Perreau displayed a disturbing idea of nationality ${ }^{79}$ where a nation would be the union of several families. These families can bond because they belong to a race, which is the base of any nation.

The arguments that Malherbe raised against propositions such as these, claiming that they were contrary to the French legal tradition and revolutionary principles, quoting Montesquieu and Adam Smith, seemed insufficient to stem the tide.

\section{Conclusions}

Although we cannot directly link scientific racism with the supporters of the ius sanguinis, the intellectual climate that favoured racial distinctions conferred a measure of scientific blessing on it. Late eighteenth-century France had developed a set of old prejudices into a fully-fledged biological theory that attempted to

75 "Son père a pu perdre sa qualité, mais il n'a pu alterer tout à fait le sang français qui coule dans les veines de son enfant", J.-J. Siméon, Discours sur la Joussance de droits civils, in Mavidal \& Laurent 1864: 165.

76 “Nous serions exposés à recevoir parmi nous ceux qui, n'ayant pas de patrie, voudraient s'enrichir de nos droits et nous infecter de leurs vices." J.-J. Siméon, Discours sur la Joussance de droits civils, in Mavidal \& Laurent 1864: 166.

77 "...l'arbre de la liberté ne produit des poisons et la mort que par la faute de ceux qui le cultivent" (Siméon 1824: 183).

78 Idem 186.

79 "Dans chaque famille d'abord, el longtemps après, dans les premiers établissements de ces sociétés plus nombreuses, formées, sous le nom de nations, de la reunión des familles, ce n'était qu'à des souvenirs fixés par la continuité des affections et des usages que l'on confiait le soin de conserver les distinctions des individus et des races" in Mavidal \& Laurent 1864: 269. 
distinguish and classify men. The ius sanguinis, the right of the blood, had gained a greater impetus to becoming the foundation of citizenship in France during the Napoleonic era and in the rest of Europe afterwards.

During the first half of the nineteenth century, given the influence of the French Civil Code, the ius soli was systematically removed from most European legal systems ${ }^{80}$ and replaced with the modern and scientific ius sanguinis. ${ }^{81}$ During the twentieth century, the ius soli abated even more once England departed from its tenets. ${ }^{82}$ Although during the early years of the twenty-first century, some exceptions are still to be found, especially with the adoption in Germany of elements of the ius soli into its legislation, ${ }^{83}$ other countries, like Denmark, abolished it altogether in 2004, except for Nordic people. ${ }^{84}$

With the growing phenomenon of immigration, the ius sanguinis-rules will only increase the number of stateless people that will be living in Europe, something essentially contrary to article 15(1) of the Universal Declaration on Human Rights of 1948 and article 1 of the 1961 Convention on the Reduction of Statelessness. By contrast, it is virtually impossible to speak of the integration of people whom the relevant legal system considers not to belong to the country where they were born. They are simply labelled as second or third generation immigrants. One might wonder where they are supposed to have immigrated from if they might never have travelled outside their home city and were born in the very state that denies them citizenship.

In the Americas, the ius soli seems to be the dominant principle. The rule was inherited from their old colonial masters, from the common-law system in the United States, and from the Siete Partidas in the case of Latin American countries. Although these nations have experienced massive immigration throughout the nineteenth and twentieth centuries, the challenges of immigration have been overcome. Probably the ius soli played an important role in this process.

80 The wave of reforms developed in parallel with the process of codification, although some countries which did not have a civil code, adopted the principle through miscellaneous legislation. The ius sanguinis was adopted in most European states during the nineteenth century: Austria (1811), Belgium (1831), Spain (1837), Prussia (1842), Italy (1865), Russia (1864), The Netherlands (1888), Norway (1892) and Sweden (1894). See Weil 2001: 19.

81 In fact, when the rules of the ius sanguinis were to be reformed in France in 1881, the ius soli was seen as a backwards relic of feudal Europe, foreign to the French traditions and modern science. See Brubaker 1993: 11.

82 Since the reform of 1914, and especially with the 1981 and 1986 acts, British legislation has been consistently undermining the application of the ius soli, to the point that what once was considered a feature of British law is nowadays something oddly exceptional. See Cesarani 1996: $11266 \mathrm{ff}$.

83 Vink \& de Groot 2012: 1121.

84 Idem 1222. 


\section{CARLOS AMUNÁTEGUI PERELLÓ}

\section{BIBLIOGRAPHY}

Anonimus (1793-1794 = 2nd year of the Republic) Cathéchisme Français Republicaine, par un sans-culotte Français (Paris)

Arangio-Ruiz, Vincenzo (1914) Le genti e le città (Messina)

Asso del Río, Jordán \& Manuel y Rodríguez, Manuel (1806) Instituciones del Derecho Civil de Castilla 7th ed vol 1 (Madrid)

Bang, Peter (1997) Antiquity between Primitivism and Modernism (Aarhus)

Bello, Andrés (1886) Derecho Internacional (Santiago)

Berdah, Jean François (2006) "Citizenship and national identity in France from the French Revolution to the present" in Ellis, Steven G, Halfdanarson, Guomundur \& Isaacs, Anne Katherine (eds) Citizenship in Historical Perspective (Pisa)

Berthencourt, Francisco (2013) Racisms, from the Crusaders to the Twentieth Century Kindle (ed) (Princeton \& Oxford)

Blackstone, William (1826) Commentaries on the Laws of England vol 1 (London)

Bonfante, Pietro (1963) Corso di diritto romano, Diritto di famiglia (Milano)

Brubaker, Rogers (1993) “De l'immigré au citoyen” Actes de la recherche en Sciences Sociales 99 (1): 3-25

Cesarani, David (1996) "The changing character of citizenship and nationality in Britain" in Cesarini, David \& Fulbrook, Mary (eds) Citizenship, Nationality and Migration in Europe (London \& New York)

Coin-Delisle, Jean-Baptiste-César (1865) "Des français par naissance. Extrait de un nouveau commentaire, inédit, du titre de la Jouissance et de la privation des droits civils" Revue Critique de Législation et de Jurisprudence 26: 214-233

Conseil d'État (1841) Discussion du Conseil d'État et du Tribunat sur le Code Civil: Avant la rédaction définitive de chacune des Lois qui le composent (Paris)

Crawford, Michael (1970) "Money and exchange in the Roman world" J of Roman Studies 60: $40-48$

Cujacius, Iacobus (1663) Opera omnia (Lutetia Parisiorum)

Dalloz, Victor \& Dalloz, Armand (1840) Jurisprudence générale du Royaume en matière civile, commerciale, criminelle et administrative et droit public (Paris)

De Boulainvilliers, Henri (1727) Histoire de l'Ancien Gouvernement de la France. Avec XIV letters historiques fur les Parlemens ou Etats-Generaux (La Haye \& Amsterdam)

Dumbraya, Costica (2014) Nationality, Citizenship and Ethno-Cultural Belonging (Hampshire)

Escriche, Joaquín (1875) Diccionario Razonado de Legislación y Jurisprudencia vol 4 (Madrid)

Finley, Moses I (1999) Ancient Economy (Berkeley \& Los Angeles)

Greene, Kevin (1990) The Archaeology of the Roman Economy (Berkeley \& Los Angeles)

Harris, William V (2011) "Poverty and destitution in the Roman Empire" in Rome's Imperial Economy (Oxford)

Kaser, Max (1960) "La famiglia romana arcaica" in Conferenze romanistiche (Milano) 


\section{RACE AND NATION}

Kehoe, Denis (2012) "Contract labor" in Scheidel, Walter (ed) The Cambridge Companion to the Roman Economy: 114-131 (Cambridge)

Leclerc, Georges-Louis (Compte) de Buffon (1834) Histoire naturelle de l'homme et de la femme (Paris)

Linneaus, Carl (1757) Systema natura per tria regna naturae vol 1, pars 1, editio decima (Holmiae)

Lo Cascio, Elio (2000) "Mercato libero e comercio amministrato in età tardoantica" in Zacagnini, Carlos (ed) Mercanti e politica nel mondo Antico (Roma)

Marcone, Arnaldo (1997) Storia dell'agricoltura romana (Roma)

Mavidal, J \& Laurent, E (1864) Archives Parlamentaires de 1787 à 1860 t 3 (Paris)

Meikle, Scott (2002) "Modernism, economics and the ancient economy" in Scheidel, Walter \& von Reden, Sitta (eds) The Ancient Economy: 233-250 (New York)

Mikkelsen, Jon M (2013) Kant and the Concept of Race. Late Eighteenth-Century Writings (New York)

Montesquieu, Charles-Louis (1772) L'esprit des lois (Paris)

Neville, Morley (2006) "Social structure and demography" in Rosenstein, Nathan \& MorsteinMarx, Robert (eds) A Companion to the Roman Republic (Oxford)

Ngaire Heuer, Jennifer (2007) The Family and the Nation: Gender and Citizenship in Revolutionary France 1789-1830 (Ithaca \& London)

Pothier, Robert-Joseph (1846) Traité des personnes et des choses (Paris)

Price, Polly J (2013) "Natural law and birthright citizenship in Calvin's Case" Yale J of Law and Humanities 9(1): 73-145

Pufendorf, Samuel (1682) De officio hominis et civis juxta legem naturalem libri duo (Cantabrigia)

Pugliese, Giovanni (1985) “Aperçu historique de la famille romaine" in Scritti giuridici scelti vol 3 (Napoli)

Santilli, Aldo (1999) "Quaedam servitus: il colonus tra legislazione e pensiero giuridico" SocietasIus. Munuscula di allievi a Feliciano Serrao: 275-292 (Napoli)

Sieyès, Emmanuel (2002) Qu'est-ce que le Tiers état (Paris)

Siméon, Joseph-Jerome (1824) "Discours prononcé dans le comité secret des Cinq-Cents, à l'occasion du renvoi que les îles de France et de la Réunion (Bourbon) avaient fait des deux Commissaires du Gouvernement Burnet et Baco" in Siméon, Joseph-Jerome, Choix de discours et opinions (Paris)

Sirks, Adrian JB (1999) “Ne colonus inscio domino suum alienet peculium” Mélanges Fritz Sturm 1: $419-430$

Sirks, Adrian J (2008) “The colonate in Justinian's reign” The J of Roman Studies 98: 120-143

Tapia García, Eugenio (1828) Febrero Novísimo vol 1 (Madrid)

Temin, Peter (2013) The Roman Market Economy (Princeton \& Oxford)

Vink, Maarten Peter \& de Groot, Gerard-René (2012) “Citizenship attribution in Western Europe: International framework and domestic trends" in Vink, Maarten Peter (ed) Migration and Citizenship Attribution. Politics and Policies in Western Europe (Oxford)

Vinnius, Arnoldus (1755) Institutionum Imperialium Commentarius vol 1 (Lugundi) 


\section{CARLOS AMUNÁTEGUI PERELLÓ}

Voci, Pasquale (1953) "Esame delle tesi del Bonfante sula Famiglia Romana Arcaica” in Studi in onore di Arangio-Ruiz vol 1 (Napoli)

Von Reden, Sitta (2012) "Money and finance" in Scheidel, Walter (ed) Cambridge Companion to Roman Economy: 266-285 (Cambridge)

Weil, Patrick (2001) "Access to citizenship: A comparison of twenty-five nationality laws" in Aleinikoff, Alexander \& Klusmeyer Douglass (eds) Citizenship Today: Global Perspectives and Practices (Washington DC)

Weil, Patrick (2008) How to be French. Nationality in the Making since 1789 trl Catherine Porter (Durham \& London)

\section{Cases}

Calvin v Smith 77 Eng Rep 377 (KB 1608)

\section{Legislation}

Acte Constitutionnel du 24 Juin 1793 (Constitution of 1793)

Constitution of the French Republic of 5 Fructidor, Year III (1795)

Constitution du 22 frimaire an VIII (Constitution of 1799)

Code civil des Français (French Civil Code) of 1804

British Nationality and Status of Aliens Act 1914 Universal Declaration on Human Rights of 1948

Convention on the Reduction of Statelessness of 1961

British Nationality Act 1981

1986 British legislation 